\title{
The taxonomic identity and phylogenetic relationships of Cercaria pugnax and C. helvetica XII (Digenea: Lecitho- dendriidae) based on morphological and molecular data
}

\author{
Olena Kudlai ${ }^{1,2}$, Virmantas Stunžènas ${ }^{1}$ and Vasyl Tkach ${ }^{3,4}$ \\ ${ }^{1}$ Laboratory of Parasitology, Nature Research Centre, Vilnius, Lithuania; \\ ${ }^{2}$ Department of Parasitology, Institute of Zoology, Kyiv, Ukraine; \\ ${ }^{3}$ Department of Biology, University of North Dakota, Grand Forks, North Dakota, USA; \\ ${ }^{4}$ Institute of Parasitology, Polish Academy of Sciences, Warszawa, Poland
}

\begin{abstract}
The present study analysed the taxonomic status and phylogenetic relationships of two species of xiphidiocercariae of the 'microcotylae' group, Cercaria pugnax La Valette St. George, 1855, from Viviparus viviparus (Linnaeus) in the Ukraine and Cercaria helvetica XII Dubois, 1928 from Bithynia tentaculata (Linnaeus) in Lithuania. Molecular phylogenetic analyses based on sequences of the ITS2 region and partial 28S gene of the nuclear rDNA revealed that both these xiphidiocercariae belong to the Lecithodendriidae Lühe, 1901 and represent larval stages of lecithodendriids parasitic in bats. Cercaria helvetica XII clustered with the typical representatives of the genus Lecithodendrium Looss, 1896, being very close, but not identical, to Lecithodendrium linstowi Dollfus, 1931. Sequences of C. pugnax matched exactly the sequences of adult Paralecithodendrium chilostomum (Mehlis, 1831). Morphological descriptions of the cercariae are included; these represent the first report of non-virgulate xiphidiocercariae belonging to the family Lecithodendriidae. Until now, the presence of glandular virgula organ in the region of the oral sucker was considered a robust synapomorphy for the Lecithodendriidae and several closely related families. Our results have shown that the relative importance of this character is in need of a re-assessment.
\end{abstract}

Keywords: Paralecithodendrium, Lecithodendrium, xiphidiocercaria, morphology, phylogeny, rDNA sequences

The taxonomic position of many digenean cercariae often cannot be established based on their morphology alone due to the scarcity of reliable taxonomic distinguishing characteristics at this stage of digenean development. Frequently, cercariae can be identified to the family or superfamily level only. The laboratory experiments on life cycles with the use of natural definitive hosts are not always feasible. Some of the difficulties in understanding trematode life cycles and identification of their larval stages may be overcome through the use of molecular techniques (Bartoli et al. 2000, Brant et al. 2006, Pina et al. 2007, Jensen and Bullard 2010, Locke et al. 2011).

As part of the study of digenean biodiversity in aquatic snails in the Ukraine and Lithuania, we have found two species of xiphidiocercariae previously described as Cercaria pugnax La Valette St. George, 1855 and Cercaria helvetica XII Dubois, 1928. Cercaria pugnax was initially described by La Valette St. George (1855) from the prosobranch Viviparus viviparus (Linnaeus) collected near Berlin, Germany (Prussia at the time). Since then, C. pugnax has been reported from several other countries in Europe (Ginetsinskaya 1968, Cichy et al. 2011). Dubois (1928) described $C$. helvetica XII as a new species of xiphidiocercaria from Bithynia tentaculata (Linnaeus) collected in Neuchâtel, Switzerland. Based on their general morphology (size of the body, sucker ratio, position of the ventral sucker, number and position of the penetration gland-cells, absence of a fin-fold along the margins of the tail), both cercariae belong to the 'microcotylae' group of xiphidiocercariae. Due to the simple morphology and very limited development of most organs, proper taxonomic allocation of these cercariae based on morphology alone was problematic. Therefore, species affiliation and potential definitive hosts of C. pugnax and C. helvetica XII remained unknown.

The goal of the present study was to reveal identity of these cercariae and their phylogenetic affinities by using DNA sequences from the cercarial stages and sequences of adult digeneans currently available in GenBank and our data. For this purpose we used sequences of the nuclear ribosomal ITS2 region and partial 28S rRNA gene. 


\section{MATERIALS AND METHODS}

Snails were collected in the Ukraine and Lithuania. In May 2012, 31 Viviparus viviparus were collected from the Dnieper River at a site on the Truchaniv Island, Kyiv, Ukraine (50²7'19"N; 30³2'42"E). In June 2013, 121 Bithynia tentaculata were collected from the Curonian Bay near the village of

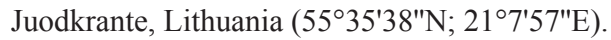

In the laboratory, snails were rinsed with water and placed individually in glass containers with aged tap water. The containers were examined daily under a stereo microscope for the presence of emerged cercariae. Morphology of the cercariae was studied on live specimens, with or without vital staining (neutral red and/ or Nile blue). Afterwards, molluscs were dissected and their tissues were compressed between two Petri dishes of different diameters and examined under microscope in order to establish the localisation of the digenean larvae. Live larvae were rinsed in water and fixed in hot $4 \%$ formaldehyde solution for morphological study and in $96 \%$ ethanol for molecular study. Drawings of the cercarial morphology were made from a combination of live and fixed cercariae using a compound microscope equipped with a drawing tube. Measurements are presented in micrometres as the range followed by the mean in parentheses. Cercariae were identified by comparison with the descriptions in La Valette St. George (1855), Dubois (1928), Ginetsinskaya (1968), and Bychovskaya-Pavlovskaya and Kulakova (1971). Nomenclature of mollusc species follows Glöer (2002).

According to the most recent revision of the Lecithodendriidae Lühe, 1901 by Lotz and Font (2008), the genus Prosthodendrium
Dollfus, 1931 is considered a synonym of Paralecithodendrium Travassos, 1921. In order to be consistent with the current classification, in the present work we use the generic name Paralecithodendrium for all previously sequenced species of Prosthodendrium.

Total genomic DNA for molecular analysis was isolated from specimens of $C$. pugnax and $C$. helvetica XII according to the protocol by Stunžènas et al. (2011) with a slight modification described in Petkevičiūte et al. (2014). DNA fragments spanning the 3 'end of $5.8 \mathrm{~S}$ rRNA gene, complete internal transcribed spacer 2 region (ITS2) and a few nucleotides at the 5 ' end of the $28 \mathrm{~S}$ gene were amplified using forward primer $3 \mathrm{~S}$ (5'-CGG TGG ATC ACT CGG CTC GTG-3') and reverse primer 28S (5'-CCT GGT TAG TTT CTT TTC CTC CGC-3') (Bowles et al. 1995). An approximately $1300 \mathrm{bp}$ long fragment at the $5^{\prime}$ end of the 28S rRNA gene was amplified using forward primer Digl2 (5'-AAG CAT ATC ACT AAG CGG-3') and reverse primer L0 (5'-GCT ATC CTG AG (AG) GAA ACT TCG-3') (Tkach et al. 1999). The amplification protocols are described in Petkevičiūtè et al. (2014). PCR products were purified and sequenced in both directions at BaseClear B.V. (Leiden, The Netherlands) using PCR primers. We also obtained new ITS2 sequences of six adult specimens of lecithodendriid digeneans (Table 1), namely Lecithodendrium linstowi Dollfus, 1931, Paralecithodendrium chilostomum (Mehlis, 1831), Paralecithodendrium hurkovaae Dubois, 1960, Paralecithodendrium longiforme (Bhalerao, 1926), Pycnoporus heteroporus (Dujardin, 1845) and Pycnoporus megacotyle (Ogata, 1939). We utilised the same DNA extracts that were used

Table 1. Digenean species used in the present study, their hosts, geographical origin of material and GenBank accession numbers for corresponding sequences. Taxa marked with asterisk were used as outgroups.

\begin{tabular}{|c|c|c|c|c|c|}
\hline \multirow{2}{*}{ Species } & \multirow{2}{*}{ Host } & \multirow{2}{*}{$\begin{array}{l}\text { Geographical } \\
\text { origin }\end{array}$} & \multicolumn{2}{|c|}{ GenBank No. } & \multirow{2}{*}{ Reference } \\
\hline & & & ITS2 & $28 \mathrm{~S}$ & \\
\hline $\begin{array}{l}\text { Lecithodendrium linstowi } \\
\text { Dollfus, } 1931\end{array}$ & Nyctalus noctula (Schreber) & Ukraine & KJ934792 & AF151919 & $\begin{array}{l}\text { present study, } \\
\text { Tkach et al. } 2000\end{array}$ \\
\hline Lecithodendrium linstowi & Pipistrellus pipistrellus (Schreber) & UK & JF784190 & JF784191 & Lord et al. 2012 \\
\hline $\begin{array}{l}\text { Lecithodendrium spathulatum } \\
\text { (Ozaki, 1929) }\end{array}$ & Pipistrellus pipistrellus & UK & JF784192 & JF784193 & Lord et al. 2012 \\
\hline $\begin{array}{l}\text { Lecithodendrium } \mathrm{sp} . \\
(=\text { Cercaria helvetica XII) }\end{array}$ & Bithynia tentaculata (Linnaeus) & Lithuania & KJ126724 & KJ126726 & present study \\
\hline $\begin{array}{l}\text { Paralecithodendrium chilostomum } \\
\text { (Mehlis, 1831) }\end{array}$ & Nyctalus noctula & Ukraine & KJ920281 & AF 151920 & $\begin{array}{l}\text { present study, } \\
\text { Tkach et al. } 2000\end{array}$ \\
\hline $\begin{array}{l}\text { Paralecithodendrium chilostomum } \\
\text { (= Cercaria pugnax) }\end{array}$ & Viviparus viviparus (Linnaeus) & Ukraine & KJ126723 & KJ126725 & present study \\
\hline $\begin{array}{l}\text { Paralecithodendrium hurkovaae } \\
\text { (Dubois, 1960) }\end{array}$ & Myotis daubentoni (Kuhl) & Ukraine & KJ920282 & AF151922 & $\begin{array}{l}\text { present study, } \\
\text { Tkach et al. } 2000\end{array}$ \\
\hline $\begin{array}{l}\text { Paralecithodendrium longiforme } \\
\text { (Bhalerao, 1926) }\end{array}$ & Myotis daubentoni & Ukraine & KJ920283 & AF151921 & $\begin{array}{l}\text { present study, } \\
\text { Tkach et al. } 2000\end{array}$ \\
\hline $\begin{array}{l}\text { Paralecithodendrium parvouterus } \\
\text { (Bhalerao, 1926) }\end{array}$ & Miniopterus schreibersi (Kuhl) & Spain & - & AY220617 & Tkach et al. 2003 \\
\hline Paralecithodendrium sp. & Pipistrellus pipistrellus & UK & JF784195 & JF784196 & Lord et al. 2012 \\
\hline $\begin{array}{l}\text { Pycnoporus heteroporus } \\
\text { (Dujardin, 1845) }\end{array}$ & Pipistrellus kuhlii (Kuhl) & Ukraine & KJ920284 & AF 151918 & $\begin{array}{l}\text { present study, } \\
\text { Tkach et al. } 2000\end{array}$ \\
\hline $\begin{array}{l}\text { Pycnoporus megacotyle } \\
\text { (Ogata, 1939) }\end{array}$ & Pipistrellus kuhli & Ukraine & KJ920285 & AF151917 & $\begin{array}{l}\text { present study, } \\
\text { Tkach et al. } 2000\end{array}$ \\
\hline $\begin{array}{l}\text { Maritrema arenaria } \\
\text { Hadley et Castle, } 1940^{*}\end{array}$ & Semibalanus balanoides (Linnaeus) & Northern Ireland & HM584171 & - & Galaktionov et al. 2012 \\
\hline $\begin{array}{l}\text { Maritrema neomi } \\
\text { Tkach, 1998* }\end{array}$ & Neomys anomalus Cabrera & Ukraine & - & AF151927 & Tkach et al. 2000 \\
\hline $\begin{array}{l}\text { Microphallus similis } \\
\text { (Jagerskiold, 1900)* }\end{array}$ & Carcinus maenas (Linnaeus) & Northern Ireland & HM584179 & - & Galaktionov et al. 2012 \\
\hline $\begin{array}{l}\text { Microphallus fusiformis } \\
\text { Reimer, 1963* }\end{array}$ & Lab. host chicken egg & UK & - & AY220633 & Tkach et al. 2003 \\
\hline $\begin{array}{l}\text { Collyriclum faba } \\
\text { (Bremser in Schmalz, 1831)* }\end{array}$ & Saxicola rubetra (Linnaeus) & Czech Republic & $\mathrm{JQ} 231122$ & JQ231122 & Heneberg and Literák 2013 \\
\hline
\end{tabular}




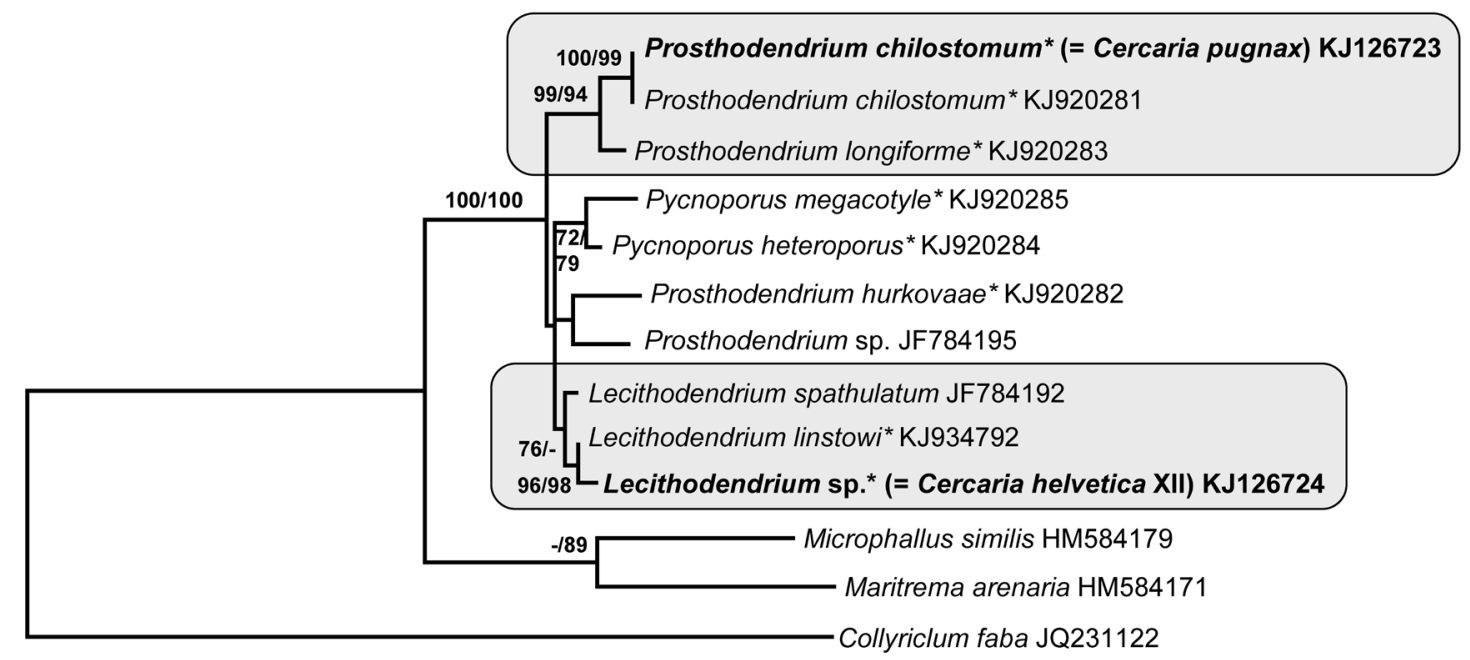

Fig. 1. Phylogenetic tree based on analysis of sequences of the ITS2 region of nuclear rDNA. Bootstrap support given for maximum likelihood/maximum parsimony analysis. Bootstrap support values lower than $70 \%$ are not shown. Sequences obtained in the present study indicated by asterisk. Shaded rectangles indicate clades containing Cercaria helvetica XII and Cercaria pugnax.

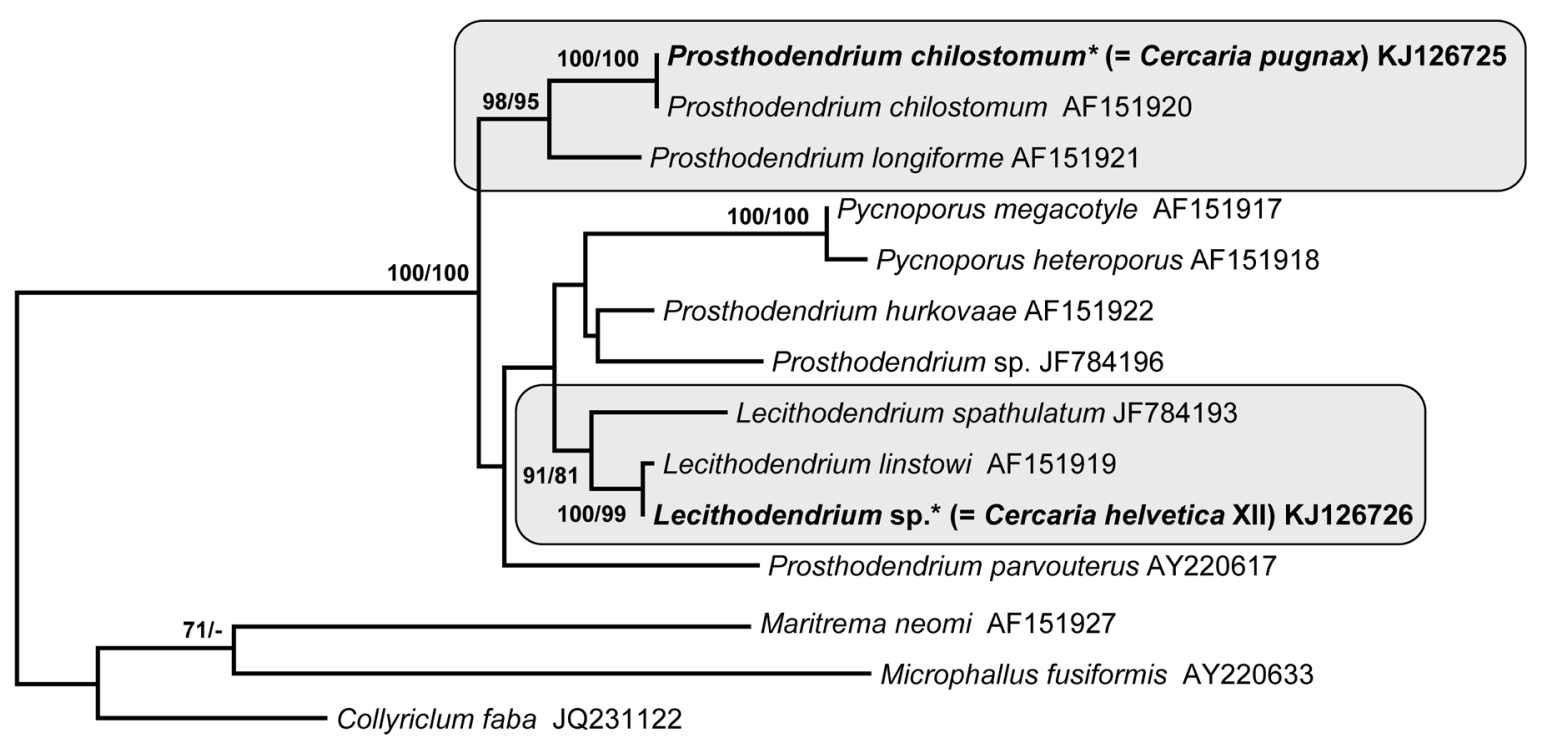

Fig. 2. Phylogenetic tree based on analysis of partial sequences of the 28S gene of nuclear rDNA. Bootstrap support given for maximum likelihood/maximum parsimony analysis. Bootstrap support values lower than $70 \%$ are not shown. Sequences obtained in the present study indicated by asterisk. Shaded rectangles indicate clades containing Cercaria helvetica XII and Cercaria pugnax.

by Tkach et al. (2000) to obtain $28 \mathrm{~S}$ sequences of these species deposited in GenBank (Table 1). In this case, forward primer d58f (5'-GCGGTGGATCACTCGGCTCGTG-3') localised in the 5.8 gene and reverse primer digl2r (5'-CCGCTTAGTGATATGCTT-3') localised at the 5 ' end of the $28 \mathrm{~S}$ gene were used for the PCR amplification and sequencing. The PCR reactions were performed following the protocols described by Tkach et al. (2003).

Contiguous sequences were assembled using Sequencher 4.7 software (Gene Codes Corporation). The new sequences were deposited in GenBank; accession numbers for both rDNA regions sequenced in this study are shown in Table 1.

Additional sequences of the Lecithodendriidae and outgroup taxa were downloaded from GenBank and included in the phylogenetic analysis and/or pairwise sequence comparisons (Table 1). For phylogenetic analyses, the sequences were aligned using ClustalW (Thompson et al. 1994) with an open gap penalty of 15 and gap extension penalty of 6.66 . The best-fit model of sequence evolution for phylogenetic analysis was estimated using $\mathrm{jModel}-$ test v. 0.1.1 software (Posada 2008). Ambiguously aligned positions have been excluded from phylogenetic analysis. Maximum likelihood (ML) and maximum parsimony (MP) phylogenetic trees were obtained and analysed using MEGA v5 (Tamura et al. 2011). Branch support was estimated by bootstrap analyses with 1000 replicates. The maximum likelihood trees were obtained using general time reversible model with a gamma distribution of rates and a proportion of invariant sites $(\mathrm{GTR}+\mathrm{G}+\mathrm{I})$ for both the ITS2 and the $28 \mathrm{~S}$ gene datasets. Gamma shape and number of invariant sites were estimated from the data. Parsimony analysis based on subtree pruning and regrafting (SPR) was used with default parsimony settings. Estimates of mean evolutionary divergence over sequence pairs within and between groups were calculated using MEGA v5 program. 


\section{RESULTS}

\section{Molecular analysis}

In Cercaria helvetica XII the amplified and sequenced fragment of the 5.8S-ITS2-28S rDNA was 454 bp long and the partial sequence of $28 \mathrm{~S}$ gene was $1113 \mathrm{bp}$. In Cercaria pugnax the 5.8S-ITS2-28S rDNA fragment was $472 \mathrm{bp}$ and the partial sequence of $28 \mathrm{~S}$ gene was $1212 \mathrm{bp}$ long. The GenBank accession numbers are presented in Table 1. BLAST searches (http://www.ncbi. nlm.nih.gov/ blast/Blast.cgi) and pairwise comparisons of ITS2 and $28 \mathrm{~S}$ sequences with the newly obtained ITS2 sequences from adult lecithodendriids demonstrated that $C$. helvetica XII was closest to Lecithodendrium linstowi obtained from two different species of bats in the United Kingdom and Ukraine (Table 1). The sequences of C. helvetica XII differed from identical sequences of two L. linstowi by 5 out of $454 \mathrm{bp}(1.1 \%)$ in the ITS2 region and by 7 out of $1010 \mathrm{bp}(0.7 \%)$ in the sequenced portion of the $28 \mathrm{~S}$ gene. Both ITS2 and 28S sequences of C. pugnax were identical to those of Paralecithodendrium chilostomum.

Two different sets of rDNA sequences were used in the phylogenetic analyses, namely the ITS2 region and partial 28S gene. Both (ML and MP) analyses of these datasets produced identical tree topologies (Figs. 1, 2). Each of the cercariae studied in this work was found in a distinct, strongly supported clade. Paralecithodendrium chilostomum was represented in the trees by the adult form obtained from bats and the larval stage C. pugnax. They clustered together with $P$. longiforme in a 94-99\% supported clade (Figs. 1, 2). Cercaria helvetica XII clustered in a 96-100\% supported clade with $L$. linstowi. In turn, these two species clustered in both trees with Lecithodendrium spathulatum (Ozaki, 1929). Among the remaining lecithodendriid taxa on the trees, two species of Pycnoporus Looss, 1899 formed a well-supported monophyletic clade, whereas the remaining topologies were weakly supported, among them the clade uniting Paralecithodendrium sp. and P. hurkovaae (Figs. 1,2) and a separate branch formed by Paralecithodendrium parvouterus (Bhalerao, 1926) only.

\section{Morphological examination}

Cercaria pugnax and Cercaria helvetica XII belong to the 'microcotylae' group of xiphidiocercariae, which includes usually very small cercariae with body less than $200 \mu \mathrm{m}$ long, with a postequatorial ventral sucker, which is smaller in size than the oral sucker and is situated behind the mid-body, and a tail without a fin-fold and not very different in length from the body.

\section{Paralecithodendrium chilostomum (Mehlis, 1831)-} cercaria

Syn. Cercaria pugnax La Valette St. George, 1855

Description (measurements based on 30 specimens). Cercariae develop in small oval sporocysts, 245-374 $\times$ 178-246 $(323 \times 210)$. Cercaria body oval, widest at its midpoint $90-180 \times 70-114(130 \times 90)$. Tegument thin, uniformly covered with tiny spines. Oral sucker rounded, subterminal, $25-45 \times 30-53(35 \times 38)$, much larger than ventral sucker. Ventral sucker subspherical, 15-25 × 15-28 $(19 \times 21)$, slightly postequatorial. Oral/ventral sucker width ratio $1: 0.30-1: 0.73(1: 0.53)$. Oral sucker armed with large stylet, 28-30 (30) long, 5-6 (5) wide at base, with rounded, distinctly enlarged base and sharp distal end with conspicuous lateral thickenings (Fig. 3B). Two pairs of large penetration gland-cells with large nuclei; first pair anterior to ventral sucker, with secretory material in form of large granules; second pair at level of ventral sucker, with secretory material in form of small granules; gland ducts extend around oral sucker and open on either side of stylet. Prepharynx very short, pharynx small, 5-13 × 8-15 $(8 \times 11)$. Oesophagus very short; almost indistinct. Caeca not observed. Excretory vesicle thin-walled, V-shaped. Flame-cell formula: $2[(2+2+2)+(2+2+2)]=24$. Excretory pore at tip of tail. Tail simple, 85-163 (127) long, 18-28 (21) wide at base, slightly shorter than body.

$\mathrm{H}$ o st: Viviparus viviparus (Linnaeus) (Mollusca: Viviparidae).

Prevalence of infection: $20 \%(n=31)$.

Site of infection: Hepatopancreas.

Locality: Dnieper River, Kyiv, Ukraine $\left(50^{\circ} 27^{\prime} 19^{\prime \prime N}\right.$; $\left.30^{\circ} 32^{\prime} 42^{\prime \prime} \mathrm{E}\right)$.

Gen Bank Acc. Nos.: KJ126723, KJ126725.

Remarks. The morphological characters and measurements of the cercaria of $P$. chilostomum correspond well to the cercaria of Lecithodendriidae gen. sp. 3 previously described by Stenko et al. (2005) from naturally infected $V$. viviparus in water bodies of the Crimea (Ukraine).

Paralecithodendrium chilostomum is a common parasite of bats (see Sharpilo and Iskova 1989), but little is known of the spectrum of its intermediate hosts. Metacercariae occur in larvae, pupae and imagoes of dragonflies Phryganea grandis (Linnaeus) and Phryganea sp. (see Brown 1933, Shevchenko 1966). Lubarskaya and Galeeva (1980) found adults of $P$. chilostomum after feeding laboratory mice with infected dragonflies Libellula quadrimaculata (Linnaeus).

The first description of the cercaria of P. chilostomum was presented by Brown (1933) who found in P. grandis yet unencysted migrating cercariae possessing a stylet and remnants of penetration gland-cells (which he called salivary glands).

The comparison of the cercaria observed in the present work with the description given by Brown (1933) revealed differences in the morphology of cercariae. The cercaria of P. chilostomum has a shorter stylet $(30 \mu \mathrm{m} v s 37 \mu \mathrm{m})$ and fewer penetration gland-cells (two pairs vs three or four pairs). These differences indicate that these cercariae belong to two different digenean species, although the metacercariae described by Brown (1933) bear general morphological similarity with adult $P$. chilostomum. It should be mentioned, however, that Paralecithodendrium is a large genus with a number of morphologically similar species that are difficult to distinguish even at adult stage let alone metacercariae.

Lecithodendrium sp. - cercaria

Fig. 3

Syn. Cercaria helvetica XII Dubois, 1928

Description (measurements based on 27 specimens). Cercariae develop in small elongate sporocysts. Body 

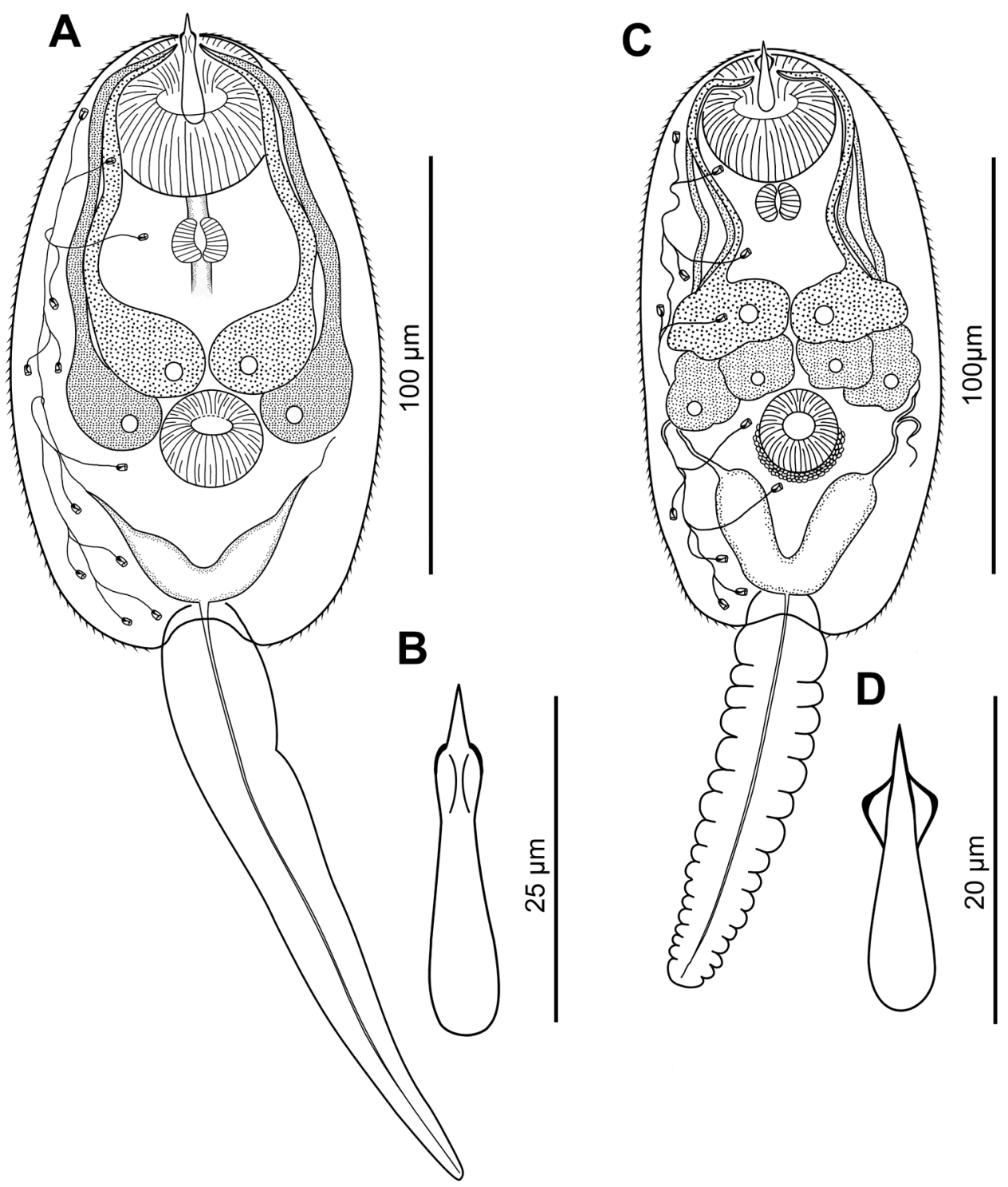

Fig. 3. Paralecithodendrium chilostomum (Mehlis, 1831) from Viviparus viviparus (A, B) and Lecithodendrium sp. from Bithynia tentaculata $(\mathbf{C}, \mathbf{D})$. A, C - whole cercaria; B, D - stylet.

small, oval, $125-158 \times 50-95(138 \times 62)$. Tegument thin, uniformly covered with fine spines. Oral sucker rounded, subterminal, 20-33 × 23-35 $(26 \times 28)$, larger than ventral sucker. Ventral sucker 20-23 (21) in diameter, located at mid-body length. Oral/ventral sucker width ratio $1: 0.57-1$ : 0.90 (1 : 0.75). Stylet 16-19 (18) long, 4 wide at base, with strongly enlarged rounded base and sharp distal end with conspicuous lateral thickenings (Fig. 3D). Three pairs of penetration gland-cells with irregular shape located anterior to ventral sucker. One pair of large gland-cells with secretory material in form of large granules located at middistance between pharynx and ventral sucker. Two smaller pairs with secretory material in form of small granules located posterior to first pair. Gland ducts open on either side of stylet. Prepharynx almost indistinct; muscular pharynx small, spherical, 10-13 × 10-13 $(11 \times 11)$. Oesophagus almost indistinct. Genital primordium represented by a compact group of cells, posterodorsal to ventral sucker. Excretory vesicle thin-walled, V-shaped. Flame-cell formula:
$2[(2+2+2)+(2+2+2)]=24$. Excretory pore subterminal. Tail simple, 100-137 (126) long, 15-23 (19) wide at base, somewhat shorter than body, with indented margins.

H o s t: Bithynia tentaculata (Linnaeus) (Mollusca: Bithyniidae). Prevalence of infection: $6 \%(n=121)$.

Site of infection: Hepatopancreas.

L o c a lity: Curonian Bay, Juodkrante, Lithuania $\left(55^{\circ} 35^{\prime} 38^{\prime \prime} \mathrm{N}\right.$; $\left.21^{\circ} 7^{\prime} 57^{\prime \prime} \mathrm{E}\right)$.

GenBank Acc. Nos.: KJ126724, KJ126726.

Remarks. Cercaria helvetica XII was first described by Dubois (1928) from B. tentaculata. Since then, this species was reported by Bychovskaya-Pavlovskaya and Kulakova (1971) from the Curonian Bay and the Neman River in Lithuania. These authors suggested that this cercaria may belong to the genus Prosthogonimus Lühe, 1899, but their light microscopy data were insufficient to elucidate the taxonomic position of this cercaria. Our phylogenetic analyses have convincingly demonstrated that $C$. helvetica 
XII is most closely related to typical representatives of Lecithodendrium Looss, 1896.

\section{DISCUSSION}

The molecular phylogenetic analyses have placed the non-virgulate cercariae described herein among the lecithodendriids parasitic in bats, namely species of Lecithodendrium and Paralecithodendrium. The tree topology resulting from the analysis of both datasets left no doubt that $C$. helvetica XII belongs to the genus Lecithodendrium (Figs. 1, 2) and is closely related to L. linstowi. However, the two species are not identical because the sequence divergence between $C$. helvetica XII and $L$. linstowi $(1.1 \%$ in ITS2 and $0.7 \%$ in $28 \mathrm{~S}$ ) is at the level usually observed among closely related congeneric species. It is noteworthy that both $28 \mathrm{~S}$ and ITS2 sequences of $L$. linstowi obtained from two different bat species in the United Kingdom and Ukraine (Tkach et al. 2000, Lord et al. 2012) were completely identical.

The exact match of both the ITS2 sequences and $28 \mathrm{~S}$ sequences of $C$. pugnax with those of adult $P$. chilostomum provides a convincing evidence that $C$. pugnax is the larval stage of $P$. chilostomum. Tkach et al. (2003) suggested that neither $P$. parvouterus nor $P$. hurkovaae belong to the genus Paralecithodendrium. Our phylogenetic analysis further corroborates this assumption, especially with respect to $P$. hurkovaae, which does not show a close affinity to Paralecithodendrium in both ITS2 and 28S trees.

The trematodes of the family Lecithodendriidae are characterised by a three-host life cycle (Lord et al. 2012) and may be parasitic as adults in birds and mammals, most prominently bats. The cercariae develop within daughter sporocysts in prosobranch molluscs. Encystment of the metacercariae occurs within aquatic insect larvae (Brown 1933, Azim 1936, Knight and Pratt 1955, Etges 1960, Besprozvannykh 1990), which may then be ingested, upon emergence of the adult insect, by a foraging bat (Lord et al. 2012). However, the complete life cycles have been elucidated in only a handful of lecithodendriid species, e.g. Acanthatrium anaplocami Etges, 1960, Acanthatrium oregonense Macy, 1939, Acanthatrium ovatum Yamaguti, 1939, Paralecithodendrium dollfusi Besprozvannykh, 1990 and Paralecithodendrium pyramidum (= Prosthodendrium parvouterus (Bhalerao, 1926) (see Azim 1936, Knight and Pratt 1955, Etges 1960, Burns 1961a,b, Besprozvannykh 1990).

All these studies reported virgulate xiphidiocercariae. We also assume that the cercaria of $P$. chilostomum de- scribed by Brown (1933) could be virgulate. He found cercariae that recently penetrated the second intermediate host and the secretions of the virgula glands may have been already used up at that point. At the beginning of penetration of the second intermediate host, the virgula organ releases material that forms a pseudocyst around the cercarial body, securing its position while it penetrates the arthropod cuticle (Lotz and Font 2008). It should be noted that a large number of virgulate cercaria described by several authors were also identified as representatives of the family Lecithodendriidae (e.g. Seitner 1945, Burns 1961a, Ginetsinskaya 1968, Stenko et al. 2005).

According to Lotz and Font (2008), the virgula organ is an important characteristic that identifies 'lecithodendriidlike' species as a natural group, the 'virgulate digeneans'. The five families thought to belong to this group are the Pleurogenidae Looss, 1899, Lecithodendriidae, Gyrabascidae Macy, 1935, Phaneropsolidae Mehra, 1935 and Leyogonimidae Dollfus, 1951. All these families contain at least one member for which the cercarial stage has been described. All of them have been found to have virgulate xiphidocercariae. Only Ganeo Klein, 1905, traditionally included in the Pleurogenidae, is known to have a non-virgulate xiphidocercaria. Brooks et al. $(1985,1989)$ considered the digeneans with virgulate cercariae a monophyletic group, the Lecithodendriidae (sensu lato). Thus, the virgula organ was used as a synapomorphy for the 'lecithodendriid-like' digenean lineages.

However, the results of the present study have demonstrated the presence of non-virgulate xiphidiocercariae among the Lecithodendriidae. This implies that the virgula organ is not an absolute synapomorphy in this group and the use of this character for broader phylogenetic and systematic assumptions is limited. Life cycles of a greater number of taxa need to be studied to adequately address the question of the evolution of the virgula organ. In the present study, DNA sequencing has once again proved to be an extremely convenient, efficient and precise way of advancing our knowledge of digenean life cycles. Further molecular studies of 'microcotylae' group of xiphidiocercariae can provide opportunities to reveal identity of numerous previously reported cercariae, elucidate their life cycles and help in a better understanding of the evolution of the Lecithodendriidae and related digenean families.

Acknowledgements. This research was supported by European Union Structural Funds project 'Postdoctoral Fellowship Implementation in Lithuania' (VP1-3.1-ŠMM-01-V-02-004).

\section{REFERENCES}

Azım M.A. 1936: On the life history of Lecithodendrium pyramidum Looss, 1896 and its development from a xiphiodiocercaria, C. pyramidum sp. nov. from Melania tuberculata. Ann. Trop. Med. Parasitol. 30: 351-354.

Bartoli P., Jousson O., Russell-Pinto F. 2000: The life cycle of Monorchis parvus (Digenea: Monorchiidae) demonstrated by developmental and molecular data. J. Parasitol. 86: 479-489.

Besprozvannykh V.V. 1990: [Life cycle of Prosthodendrium dollfusi sp. n. and Acanthotrium ovatum (Trematoda: Lecithode- ndriidae) in the south of the Far East of the USSR.] Parazitologiya 24: 431-439. (In Russian.)

Bowles J., Blair D., McManus D.P. 1995: A molecular phylogeny of the human schistosomes. Mol. Phylogenet. Evol. 4: 103-109.

Brant S.V., Morgan J.A., Mkoji G.M., Snyder S.D., RaJAPAKSE R.P., LOKER E.S. 2006: An approach to revealing blood fluke life cycles, taxonomy, and diversity: provision of key 
reference data including DNA sequence from single life cycle stages. J. Parasitol. 92: 77-88.

Brooks D.R., Bandoni S.M., Macdonald C.A., O'Grady R.T. 1989: Aspects of the phylogeny of the Trematoda Rudolphi, 1808 (Platyhelminthes: Cercomeria). Can. J. Zool. 67: 2609-2624.

Brooks D.R., O'Grady R.T., Glen D.R. 1985: Phylogenetic analysis of the Digenea (Platyhelminthes: Cercomeria) with comments on their adaptive radiation. Can. J. Zool. 63: 411-443.

Brown F.J. 1933: On the excretory system and life history of Lecithodendrium chilostomum (Mehl.) and other bat trematodes, with a note on the life history of Dicrocoelium dendriticum (Rudolphi). Parasitology 25: 317-328.

BuRns W.C. 1961a: Six virgulate xiphidocercariae from Oregon, including redescriptions of Allassogonoporus vespertilionis and Acantharium oregonense. J. Parasitol. 47: 919-925.

BURns W.C. 1961b: Penetration and development of Allassogonoporus vespertilionis and Acanthatrium oregonense (Trematoda: Lecithodendriidae) cercariae in caddis larvae. J. Parasitol. 47: 927-932.

Bychovskaya-Pavlovskaya I.E., Kulakova A.P. 1971: [Cercariae of Bithynia tentaculata and B. leachi from the Kurish Gulf.] Parazitologiya 5: 222-232. (In Russian.)

Cichy A., Faltýnková A., ŻBikowska E. 2011: Cercariae (Trematoda, Digenea) in European freshwater snails - a checklist of records from over one hundred years. Folia Malacol. 19: 165-189.

Dubois G. 1928: Les cercaires de la region de Neuchâtel. Bull. Soc. Neuchâtel. Sci. Nat. 53: 1-177.

Etges F.J. 1960: On the life history of Prosthodendrium (Acanthatrium) anaplocami $\mathrm{n}$. sp. (Trematoda: Lecithodendriide). J. Parasitol. 46: 235-240.

Galaktionov K.V, Blasco-Costa I., Olson P.D. 2012: Life cycles, molecular phylogeny and historical biogeography of the 'pygmaeus' microphallids (Digenea: Microphallidae): widespread parasites of marine and coastal birds in the Holarctic. Parasitology 139: 1346-1360.

Ginetsinskaya T.A., Dobrovolskii A.A. 1968: [Larval trematode fauna of freshwater mollusks of the Volga Delta. Part III. Furcocercariae (Cyathocotylidae) and xiphidiocercariae.] Proceedings of the Astrakhan state nature reserve 11: 29-95. (In Russian.)

Glöer P. 2002: Die Süsswassergastropoden Nord- und Mitteleuropas. Bestimmungsschlüssel, Lebensweise, Verbreitung. Die Tierwelt Deutschlands 73. ConchBooks, Hackenheim, 326 pp.

Heneberg P., Literák I. 2013: Molecular phylogenetic characterization of Collyriclum faba with reference to its three hostspecific ecotypes. Parasitol. Int. 62: 262-267.

Jensen K., Bullard S.A. 2010: Characterization of a diversity of tetraphyllidean and rhinebothriidean cestode larval types, with comments on host associations and life-cycles. Int. J. Parasitol. 40: 889-910.

Knight R.A., Pratt I. 1955: The life-histories of Allassogonoporus vespertilionis Macy and Acanthatrium oregonense Macy (Trematoda: Lecithodendriidae). J. Parasitol. 41: 248-255.

La Valette St. George A. 1855: Symbolae ad Trematodum Evolutionis Historiam. Dissertation, Berlin, 40 pp.

Locke S.A., McLaughlin J.D., Lapierre A.P., Johnson P.T.J., MARCOGLIESE D.J. 2011: Linking larvae and adults of Apharyngostrigea cornu, Hysteromorpha triloba, and Alaria mustelae (Diplostomoidea: Digenea) using molecular data. J. Parasitol. 97: $846-851$
Lord J.S., Parker S., Parker F., Brooks D.R. 2012: Gastrointestinal helminths of pipistrelle bats (Pipistrellus pipistrellus/ Pipistrellus pygmaeus) (Chiroptera: Vespertilionidae) of England. Parasitology 139: 366-374.

Lotz J.M., Font W.F. 2008: Family Lecithodendriidae Lühe, 1901. In: R.A. Bray, A. Jones and D.I. Gibson (Eds.), Keys to the Trematoda. Volume 3. CABI, Wallingford and Natural History Museum, London, pp. 527-536.

Lubarskaya O.D., GaleEva L.KH. 1980: [Rates of infection with trematode metacercariae of dragonflies in the Tatar ASSR.]. Problems of Parasitology of Aquatic Invertebrates: 68-70. (In Russian.)

Petkevičiūté R., StunžÉnas V., Stanevičiūtė G. 2014: Differentiation of European freshwater bucephalids (Digenea: Bucephalidae) based on karyotypes and DNA sequences. Syst. Parasitol. 87: 199-212.

Pina S.M.R., Russell-Pinto F., Rodrigues P. 2007: Clarification of Cercaria sevillana (Digenea: Microphallidae) life cycle using morphological and molecular data. J. Parasitol. 93: 318322.

Posada D. 2008: jModelTest: Phylogenetic model averaging. Mol. Biol. Evol. 25: 1253-1256.

Seitner P.G. 1945: Studies on five new species of xiphidiocercariae of the virgule type. J. Parasitol. 31: 272-281.

Sharpilo V.P., Iskova N.I. 1989: [Fauna of the Ukraine. Vol. 34. Trematoda. Part 3. Plagiorchiata]. Naukova dumka, Kiev, 279 pp. (In Russian.)

SHEVChenko N.N. 1966: [Helminth fauna of some species of mammals of valley of Seversky Donets (Kharkiv oblast) and their influence on the composition and circulation of parasites of water biocenosis.] Materialy Nauchnoy Konferentsii VOG 3: 321-327. (In Russian.)

Stenko R., Korol E., Dulitskil A.I. 2005: [Lecithodendriids - parasites of the Chiroptera from the protected areas of the Crimea.]. Materialy III Nauchnoy Konferentsii "Zapovedniky Kryma: zapovednoe delo, bioraznoobrazie, ekoobrazovanie", Simferopol, Ukraine, 22 April 2005, pp. 83-87. (In Russian.)

Stunžėnas V., Petrevičíutė R., Stanevičıūté G. 2011: Phylogeny of Sphaerium solidum (Bivalvia) based on karyotype and sequences of 16S and ITS1 rDNA. Centr. Eur. J. Biol. 6: 105-117.

Tamura K., Peterson D., Peterson N., Stecher G., Nei M., KUMAR S. 2011: MEGA5: molecular evolutionary genetics analysis using maximum likelihood, evolutionary distance, and maximum parsimony methods. Mol. Biol. Evol. 24: 2731-2739.

Thompson J.D., Higgins D.G., Gibson .T.J. 1994: CLUSTAL W: improving the sensitivity of progressive multiple sequence alignment through sequence weighting, position-specific gap penalties and weight matrix choice. Nucl. Acids Res. 22: 4673-4680.

Tkach V., Grabda-Kazubska B., Pawlowski J., Swiderski Z. 1999: Molecular and morphological evidences for close phylogenetic affinities of the genera Macrodera, Leptophallus, Metaleptophallus, and Paralepoderma (Digenea, Plagiorchioidea). Acta Parasitol. 44: 170-179.

Tкасн V., Littlewood D.T.J., Olson P.D., Kinsella J.M., SWIDERSKi Z. 2003: Molecular phylogenetic analysis of the Microphalloidea Ward, 1901 (Trematoda: Digenea). Syst. Parasitol. 56: $1-15$.

Tkach V., Pawlowski J., Mariaux J. 2000: Phylogenetic analysis of the suborder Plagiorchiata (Platyhelminthes, Digenea) based on partial lsrDNA sequences. Int. J. Parasitol. 30: 83-93. 